University of Nebraska - Lincoln

DigitalCommons@University of Nebraska - Lincoln

Agronomy \& Horticulture - Faculty Publications

Agronomy and Horticulture Department

May 2003

\title{
Tagging and mapping of genes and QTL and molecular marker- assisted selection for traits of economic importance in bean and cowpea
}

\author{
J. D. Kelly \\ Michigan State University \\ P. Gepts \\ University of California, 1 Shields Avenue, Davis, CA \\ P. N. Miklas \\ USDA-ARS-IAREC \\ D. P. Coyne \\ University of Nebraska-Lincoln
}

Follow this and additional works at: https://digitalcommons.unl.edu/agronomyfacpub

Part of the Plant Sciences Commons

Kelly, J. D.; Gepts, P.; Miklas, P. N.; and Coyne, D. P., "Tagging and mapping of genes and QTL and molecular marker-assisted selection for traits of economic importance in bean and cowpea" (2003). Agronomy \& Horticulture -- Faculty Publications. 73.

https://digitalcommons.unl.edu/agronomyfacpub/73

This Article is brought to you for free and open access by the Agronomy and Horticulture Department at DigitalCommons@University of Nebraska - Lincoln. It has been accepted for inclusion in Agronomy \& Horticulture -Faculty Publications by an authorized administrator of DigitalCommons@University of Nebraska - Lincoln. 


\title{
Tagging and mapping of genes and QTL and molecular marker-assisted selection for traits of economic importance in bean and cowpea
}

\author{
J.D. Kelly ${ }^{\mathrm{a}, *}$, P. Gepts ${ }^{\mathrm{b}}$, P.N. Miklas ${ }^{\mathrm{c}}$, D.P. Coyne ${ }^{\mathrm{d}}$ \\ ${ }^{\mathrm{a} C}$ Crop and Soil Sciences, Michigan State University, East Lansing, MI 48824, USA \\ ${ }^{\mathrm{b}}$ Agronomy and Range Science, University of California, 1 Shields Avenue, Davis, CA 95616-8515, USA \\ ${ }^{\mathrm{c}}$ USDA-ARS-IAREC, 24106 N. Bunn Rd., Prosser, WA 99350, USA \\ ${ }^{\mathrm{d}}$ Department of Agronomy and Horticulture, University of Nebraska, Lincoln, NE 68583, USA
}

\begin{abstract}
Bean/Cowpea Collaborative Research Support Program (B/C CRSP) scientists have successfully developed integrated consensus maps of the 11 linkage groups (LGs) in both bean (Phaseolus vulgaris L.) and cowpea (Vigna unguiculata $\mathrm{L}$. Walp). The bean map is approximately $1200 \mathrm{cM}$ with some 500 markers and an additional 500 markers shared with other bean maps. The cowpea map spans $2670 \mathrm{cM}$ with over 400 markers. In addition to molecular markers, both maps include map locations of defense genes and phenotypic traits for disease and insect resistance, seed size, color and storage proteins, pod color and those traits associated with the domestication syndrome in bean. Since the bean and cowpea maps were developed independently, LGs with the same number probably refer to non-syntenic groups. Map locations of major resistance genes in bean are revealing gene clusters on LGs B1, B4, B7, and B11 for resistance to bean rust, anthracnose, common bacterial blight and white mold. Gene tagging and marker-assisted selection for disease resistance has progressed to a point where the indirect selection for resistance to a number of major diseases is now routine in bean breeding programs both in the US and overseas.
\end{abstract}

(C) 2003 Elsevier Science B.V. All rights reserved.

Keywords: Domestication; Disease resistance; Epistasis; Indirect selection; Introgression; Linkage; Pathogens; Phaseolus vulgaris; Plant breeding; Vigna unguiculata

\section{Introduction}

One of the missions of the Bean/Cowpea Collaborative Research Support Program (B/C CRSP) is to advance the science of bean and cowpea improvement through partnerships among US and Host Country Institutions in Latin America and East and West Africa.

\footnotetext{
* Corresponding author. Tel.: +1-517-355-0205; fax: +1-517-353-3955.

E-mail address: kellyj@msu.edu (J.D. Kelly).
}

The type of research dictated by those collaborative agreements tends to be applied given the many problems that confront bean and cowpea production in different host countries. Since training activities are part of the overall mission, more basic research activities have been incorporated into the B/C CRSP to strengthen the training component and advance the overall research both in the US and overseas. One area where the CRSP has made major inroads has been in the tagging and mapping of genes of economic importance in both bean and cowpea. Early mapping 
Table 1

Overview of bean mapping populations with their segregating characters, cited in this text

\begin{tabular}{|c|c|c|c|}
\hline \multicolumn{2}{|l|}{ Population (generation) } & \multirow[t]{2}{*}{ Traits segregating } & \multirow[t]{2}{*}{ Source } \\
\hline Parents & Abbreviation & & \\
\hline BAT93 $\times$ Jalo EEP558 $\left(\mathrm{F}_{2}\right)$ & $\mathrm{BJ}$ & $\begin{array}{l}\text { Resistance to: BCMV, X. axonopodis, } \\
\text { C. lindemuthianum, Phaeoisariopsis griseola, } \\
\text { U. appendiculatus, Rhizobium spp.; V, C }\end{array}$ & $\begin{array}{l}\text { Gepts et al. (1993), Nodari et al. } \\
\text { (1993a) and Freyre et al. (1998) }\end{array}$ \\
\hline BAT93 $\times$ Jalo $\operatorname{EEP558~}(\mathrm{RI})^{\text {a }}$ & $\mathrm{BJ}$ & & \\
\hline Midas $\times$ G12873 $(\mathrm{RI})$ & MG & $\begin{array}{l}\text { Domestication syndrome: } P p d, f i n, S t, y, \\
P ; \text { phenology, number of nodes and pods, } \\
\text { seed weight; dormancy }\end{array}$ & Koinange et al. (1996) \\
\hline XR235-1-1 × DIACOL Calima $(B C)$ & $\mathrm{XD}$ & Resistance to: $X$. axonopodis & $\begin{array}{l}\text { Vallejos et al. (1992) and } \\
\text { Yu et al. (1998) }\end{array}$ \\
\hline Corel $\times$ EO2 $(\mathrm{BC})$ & $\mathrm{CE}$ & Resistance to: C. lindemuthianum; $M s-8$, Sgou & Adam-Blondon et al. (1994) \\
\hline BAC6 $\times$ HT7719 $(\mathrm{RI})$ & $\mathrm{BH}$ & CBB, web blight, rust & Jung et al. (1996a) \\
\hline Dorado $\times$ XAN176 $(\mathrm{RI})$ & DX & Ashy stem blight, BGMV, CBB, rust & Miklas et al. $(1996,2000 a)$ \\
\hline PC-50 $\times$ XAN159 $(\mathrm{RI})$ & PX & $\mathrm{CBB}, C, V$ seed weight, rust, white mold & $\begin{array}{l}\text { Jung et al. }(1997) \text { and } \\
\text { Park et al. }(2000,2001)\end{array}$ \\
\hline $\mathrm{A} 55 \times \mathrm{G} 122(\mathrm{RI})$ & AG & $\begin{array}{l}\text { Performance in: Andean } \times \text { Mesoamerican } \\
\text { crosses, } C \text {, white mold resistance }\end{array}$ & $\begin{array}{l}\text { Johnson et al. (1997) and } \\
\text { Miklas et al. (2001a) }\end{array}$ \\
\hline Benton $\times$ NY6020-4 (RI) & B60 & White mold & Miklas et al. (2001b) \\
\hline OAC Seaforth $\times$ OAC-95-4 & $\mathrm{S} 95$ & $\mathrm{CBB}$ & Tar'an et al. (2001) \\
\hline Belneb-RR-1 × A55 (RI) & BA & Halo blight, CBB, BCMV & Ariyarathne et al. (1999) \\
\hline Bunsi $\times$ Newport $(\mathrm{RI})$ & $\mathrm{BN}$ & White mold & Kolkman and Kelly (2003) \\
\hline Montcalm $\times$ FR266 $(\mathrm{RI})$ & MF & Fusarium root rot & Schneider et al. (2001) \\
\hline Montcalm × California DRK82 (RI) & $\mathrm{MC}$ & Canning quality traits in dark red kidney beans & Posa-Macalincag et al. (2002) \\
\hline
\end{tabular}

${ }^{\mathrm{a}} \mathrm{RI}$ : recombinant inbred populations; BC: backcross populations.

activities involving molecular markers in bean were performed by Weeden (1984), Weeden and Liang (1985), Bassett (1988, 1991), Gepts (1988), Arndt and Gepts (1989) and Koenig and Gepts (1989). These activities have expanded at other institutions to research focused on tagging of major resistance genes and the elucidation of more complex resistance traits through QTL analysis (Table 1). In some instances collaborating scientists in the host country collected the phenotypic data where the disease problem existed and as a result, the marker technology has now been exported to host country scientists who see the potential use of the technology in their local training and improvement programs. Since the topic of the mapping and tagging of major disease resistance and other genes in bean was recently reviewed by the authors (Gepts, 1999; Kelly and Miklas, 1999), the present review will focus on CRSP-supported research on the development and current status of the integrated maps in bean and cowpea, the history of gene tagging in bean, and its current application in marker-assisted selection (MAS) experiments being conducted by CRSP scientists.

\section{Integrated bean linkage map}

Because of the multiplicity of breeding objectives in bean, which include disease and pest resistance, tolerance to abiotic stresses, domestication syndrome, crop quality, etc. (Gepts, 1998), no single population would segregate for all the economic traits of interest. Thus, genes for these traits have been located on maps developed from different segregating populations. The challenge, therefore, has been to allow a comparison among these maps so that the linkage relations among the different genes can be identified. An additional complication has been that each map was initially established with different markers. Therefore, with a few exceptions, the different maps included few shared markers. The exceptions included the use of shared RFLP markers between the map developed at the University of California, Davis (Nodari et al., 1993a) and the map developed at the University of Paris XI (Adam-Blondon et al., 1994), along with a few isozyme and seed protein markers also shared with the map developed at the University of Florida 
(Vallejos et al., 1992). The total number of the shared markers, however, remained quite small.

A deliberate effort was therefore initiated to make a consensus map by determining the segregation in a core mapping population of a limited number of markers from each linkage group (LG) on the different maps. The core mapping population chosen by Freyre et al. (1998) was the recombinant inbred population resulting from the cross between the genotypes BAT93 and Jalo EEP558. The BAT93 $\times$ Jalo EEP558 (BJ) population displays a high level of diversity for RFLP and other markers because the parents belong to the Middle American and Andean gene pools, respectively (Nodari et al., 1992; McClean et al., 2002), and segregates for multiple host-microorganism interactions (Nodari et al., 1993b; Geffroy et al., 1999). For each of the LGs, a minimum of two (or more) markers from the different maps were mapped in the BJ population. The maps involved included the Davis map (Nodari et al., 1993a; Freyre et al., 1998), the Paris map (Adam-Blondon et al., 1994), the Florida map (Vallejos et al., 1992), and the Nebraska-Wisconsin maps (Jung et al., 1996a, 1997-1999). The former three maps are based on RFLP markers, wholly or in their majority. The latter group of maps is based on RAPD markers.

This strategy has allowed us to correlate and coorient the different LGs and to determine that the different LGs are collinear among maps when more than two markers were used per LG (Freyre et al., 1998; Gepts, 1999). While there is no detailed correlation (i.e., over short distances of the order of 10$15 \mathrm{cM}$ or less) among the LGs of the different maps, the information developed thus far allows at least a rough comparison of the location for genes or Quantitative Trait Loci (QTL) placed on independent maps. A similar strategy was followed more recently by Vallejos et al. (2001) to further correlate the RAPD maps from the Nebraska-Wisconsin with the Florida RFLP map. The reader is referred to the following sources of figures illustrating the integrated map: Gepts (1999, pp. 389-400), Freyre et al. (1998, Fig. 1) and Vallejos et al. (2001, Fig. 1); http://agronomy.ucdavis.edu/gepts/mapdata2.htm.

The total map length of the consensus map is approximately $1200 \mathrm{cM}$ (Gepts, 1999) and the average relationship between genetic and physical distances is approximately $500 \mathrm{~kb} / \mathrm{cM}$, which was verified around the Phs (phaseolin) locus on LG B7 (Llaca and Gepts, 1996). Further measurements are, however, needed to examine the range of variation of this relationship. The core map possesses some 550 markers, including RFLP, RAPD, SCAR, allozyme, and seed protein markers; when considering markers from the other, correlated maps, at least 1000 markers have been mapped which would average one marker per 1-2 cM (Freyre et al., 1998; Gepts, 1999).

Further developments in the characterization of the bean genome include the development of bacterial artificial chromosome (BAC) libraries in the genotypes Sprite (Vanhouten and Mackenzie, 1999) and BAT93 (Kami and Gepts, 2000). An important outcome of the development of these libraries will be the identification of additional markers, either microsatellite or single nucleotide polymorphism (SNP) markers (Melotto and Kelly, 2001). Furthermore, a preliminary study of the existence of microsatellite markers in the bean genome was conducted by Yu et al. (1999, 2000b), who were able to map some 15 SSR markers onto the core linkage map.

\section{Integrated cowpea linkage map}

Genetic maps of cowpea have been established by Fatokun et al. (1992, 1993), Menancio-Hautea et al. (1993), Menéndez et al. (1997), Ubi et al. (2000) and Ouédraogo et al. (2002). Of these, the latter, building on the earlier version developed by Menéndez et al. (1997), is the most current and complete map and will be discussed in this article (http://pubs.nrc-cnrc.gc.ca/ cgi-bin/rp/rp2_abst_f?gen_g01-102_45_ns_nf_gen1-02). This map was established in the recombinant inbred population IT84S-2049 $\times$ 524B $(n=94)$ developed by the CRSP project at the University of California, Riverside. IT84S-2049 is an advanced breeding line developed at IITA in Nigeria for multiple disease and pest resistance and has resistance to several races of blackeye cowpea mosaic virus (B1CMV) and to virulent root-knot nematodes in California (Menéndez et al., 1997). Line 524B is a black-eyed cowpea that shows resistance to Fusarium wilt and was developed at the University of California, Riverside, from a cross between cultivars CB5 and CB3, which encompasses the genetic variability that was available in cowpea cultivars in California. 
In contrast with bean, domesticated cowpea consists of a single gene pool. The genetic diversity in this gene pool for RFLPs was limited and alternative markers have been pursued, including RAPDs (Menéndez et al., 1997) and AFLPs (Ouédraogo et al., 2002), which detect a larger number of polymorphic loci. The current map of cowpea consists of 11 LGs spanning a total of $2670 \mathrm{cM}$, with an average distance of approximately $6 \mathrm{cM}$ between markers. It includes 242 AFLP, 18 disease or pest resistance-related markers (Ouédraogo et al., 2002) and 133 RAPD, 39 RFLP, and 25 AFLP markers from the original map of Menéndez et al. (1997) for a total of 441 markers, of which 432 were assigned to a LG. Among these markers loci, genes for a number of biochemical and phenotypic traits have been located on this map. These include $C$, a general color factor, and $P$, for purple pod color, on LG4 (according to the numbering system of Ouédraogo et al., 2002, LGs on the bean and cowpea maps have been numbered independently, thus, LGs with the same number on the two maps probably refer to non-syntenic groups), a $35 \mathrm{kDa}$ dehydrin protein, implicated in chilling tolerance during emergence (LG2; Ismail et al., 1999), and markers for resistance to Striga gesnerioides races 1 and 3 (LG1 and LG6), cowpea mosaic virus (CPMV) and cowpea severe mosaic virus (CPSMV) (two distinct loci on LG2), B1CMV (LG8), southern bean mosaic virus (SBMV) (LG6), Fusarium wilt (LG6, distinct from the previous locus), and root-knot nematodes ( $R k$ on LG1) (Ouédraogo et al., 2002). Resistance gene candidates (RGCs) were also placed by RFLP analysis in various locations on the integrated cowpea map, including LG3, LG5, and LG9. Nevertheless, none of the RGC loci cosegregated with disease resistance phenotypes, suggesting that additional mapping for both RGCs and phenotypic disease resistance traits should be pursued in cowpea.

\section{Mapping of domestication-related traits in bean}

Wild and domesticated traits can be distinguished by a set of traits termed the domestication syndrome. These traits were selected during and after domestication and ultimately conferred adaptation to a cultivated environment and increased the appeal of beans to consumers. The two most important traits distinguishing domesticated beans from their wild counterparts are the lack of seed dormancy and lack of seed dispersal mechanisms. Additional traits include a marked trend towards a more compact growth habit, including its more extreme form, the bush, determinate habit (also called Type I by Singh, 1982), photoperiod insensitivity, which allowed cultivation under environments of different latitudes including temperate latitudes, and development of new pod types (including snap bean types) and new seed color or color pattern types, with larger seed size, which attracted the interest of consumers.

The inheritance of several domestication traits was investigated by segregation analysis in the recombinant inbred population Midas $\times$ G12873. Midas is a snap bean cultivar with yellow (wax) pods, with phaseolin and isozyme markers typical of the Andean gene pool. G12873 is a Middle American wild bean, with a unique phaseolin type suggesting that it may not have contributed to the domesticated gene pool. The population was evaluated both in Colombia (under short days) and in the summer in Davis, CA (long days) to evaluate traits under different photoperiods. The results of the analysis conducted by Koinange et al. (1996) showed that the inheritance of domestication traits was often (but not always) controlled by major genes or major QTL $\left(R^{2}>30 \%\right)$. Exceptions were internode length and harvest index. Over half of the phenotypic variation for many traits in the recombinant inbred population could be accounted for in genetic terms, suggesting a high heritability of these traits. In addition, many of the genes controlling these traits appeared to be linked or at least to be concentrated on a few LGs (B1-B3, and B7). Of note here is the linkage of genes on $\mathrm{B} 1$, including the major genes fin (determinacy) and Ppd (photoperiod sensitivity) and QTL for internode length and harvest index. The presence of a QTL for harvest index linked to the Ppd may be a result of pleiotropic action as suggested by Wallace et al. (1993). Alternatively, it could represent a distinct gene. The linkages on B1 between fin and $P p d$ and between $S t$ (presence of strings or fibers in the pods) and $B$ (greenish-brown seedcoat color) on B2 confirmed earlier observations of Coyne (1967) and Lamprecht (1961). Although this experiment was conducted primarily to study the domestication syndrome, the choice of parents allowed us to place on the molecular linkage map several genes that had been 
located previously on the classical bean linkage map (Bassett, 1991).

An important characteristic distinguishing domesticated beans from their wild progenitors is the astonishing diversity of seed types. A bean seed type can be characterized by its size (or weight), shape, and color or color pattern. Recent investigations have clarified the genetic control of the different colors and color patterns in bean seeds (Beninger et al., 2000). The $P$ gene, which is the basic gene determining the presence (colored) or absence (white) of pigments in seeds (and elsewhere in the plant), and the asp gene, responsible for the dullness of the seedcoat, are located on LG B7 (Arndt and Gepts, 1989; Koinange et al., 1996), whereas the color modifying $B$ gene is tightly linked to the $I$ gene for bean common mosaic virus (BCMV) resistance on B2 (Temple and Morales, 1986; Nodari et al., 1993a). Other seedcoat color genes have also been mapped onto the core linkage map (McClean et al., 2002). These include the $C$ (B8), $G$ (B4), $V(\mathrm{~B} 6)$, and $G y$ (B8) color genes. The latter may actually be an allele of the $C$ locus or be tightly linked to this locus. Several color pattern genes were also located on this map including the $Z$ (or $D$ ) and $T$ genes on B3 and B9, respectively, and the Bip and $L$ (or $J$ ) loci on B10.

The inheritance of seed weight has been determined in three populations. One of these involved the cross between a snap bean and a wild bean, mentioned earlier (Koinange et al., 1996). The two others involved domesticated parents (R. Nodari, P. Gepts, unpublished results; Park et al., 2000). Koinange et al. (1996) identified three QTL, on B1 and B7 (two loci). R. Nodari, P. Gepts (unpublished results) identified QTL on LGs B1, B3, B4, and B7 in population BJ. Park et al. (2000) identified seed weight QTL on LGs B3-B7. One of the QTL identified on B7 by Koinange et al. (1996) and those identified by Nodari (1992) and Park et al. (2000) likely are the same and may correspond to the Phs (phaseolin) seed protein locus. This locus was identified by Delaney and Bliss (1991a,b) and Johnson et al. (1997) as playing a role in seed weight (in addition to protein content) in a wide range of genetic backgrounds.

Information on the map location of domestication syndrome genes should facilitate the introgression of additional genetic diversity from not only wild beans but exotic domesticated beans as well. Firstly, provided that genes for domestication and those of agronomic interest such as disease resistance are not tightly linked, then breeders will be able to obtain recombinant lines with the desired agronomic trait(s) and the domesticated phenotype. It is therefore imperative to systematically map genes of economic importance to evaluate their potential for introgression into the domesticated gene pool. Secondly, this information provides some suggestions as to a possible conversion strategy to adapt wild bean germplasm to temperate conditions for their subsequent agronomic evaluation. The key traits to introduce into wild germplasm to increase their adaptation would be photoperiod insensitivity, lack of seed dormancy and dispersal, and a more compact growth habit. This could be achieved by developing markers linked to specific regions controlling these traits on LGs B1-B3 (Fig. 1). An inbred backcross strategy combining selection for these domesticated traits could lead to conversion of wild germplasm for adaptation to temperate and cultivated growing conditions. Thirdly, a similar but simplified system involving only photoperiod insensitivity with or without a more compact growth habit could be developed for the conversion of domesticated exotic germplasm.

\section{Tagging genes of economic importance in bean}

In the 1980s, CRSP scientists effectively used isozyme and mitochondrial RFLP markers to characterize the relatedness between landrace bean cultivars in east Africa (Khairallah et al., 1990). The paucity of isozyme markers restricted their application in breeding, so the potential of RAPD markers as a rapid, costeffective tool for the indirect selection of traits, once linkages between the marker and the trait of interest have been identified, was immediately recognized by bean breeders. Although RAPD markers are difficult to reproduce (Weeden et al., 1992), CRSP researchers developed and utilized this marker system to tag major disease resistance genes in bean (Kelly, 1995). To facilitate the identification of linked markers, mapping populations and methods were developed which included the use of near-isogenic lines (NILs), bulked segregant analysis (BSA; Michelmore et al., 1991), and progeny tests. To improve the reproducibility of previously identified RAPD markers, sequence characterized amplified region (SCAR) markers, 


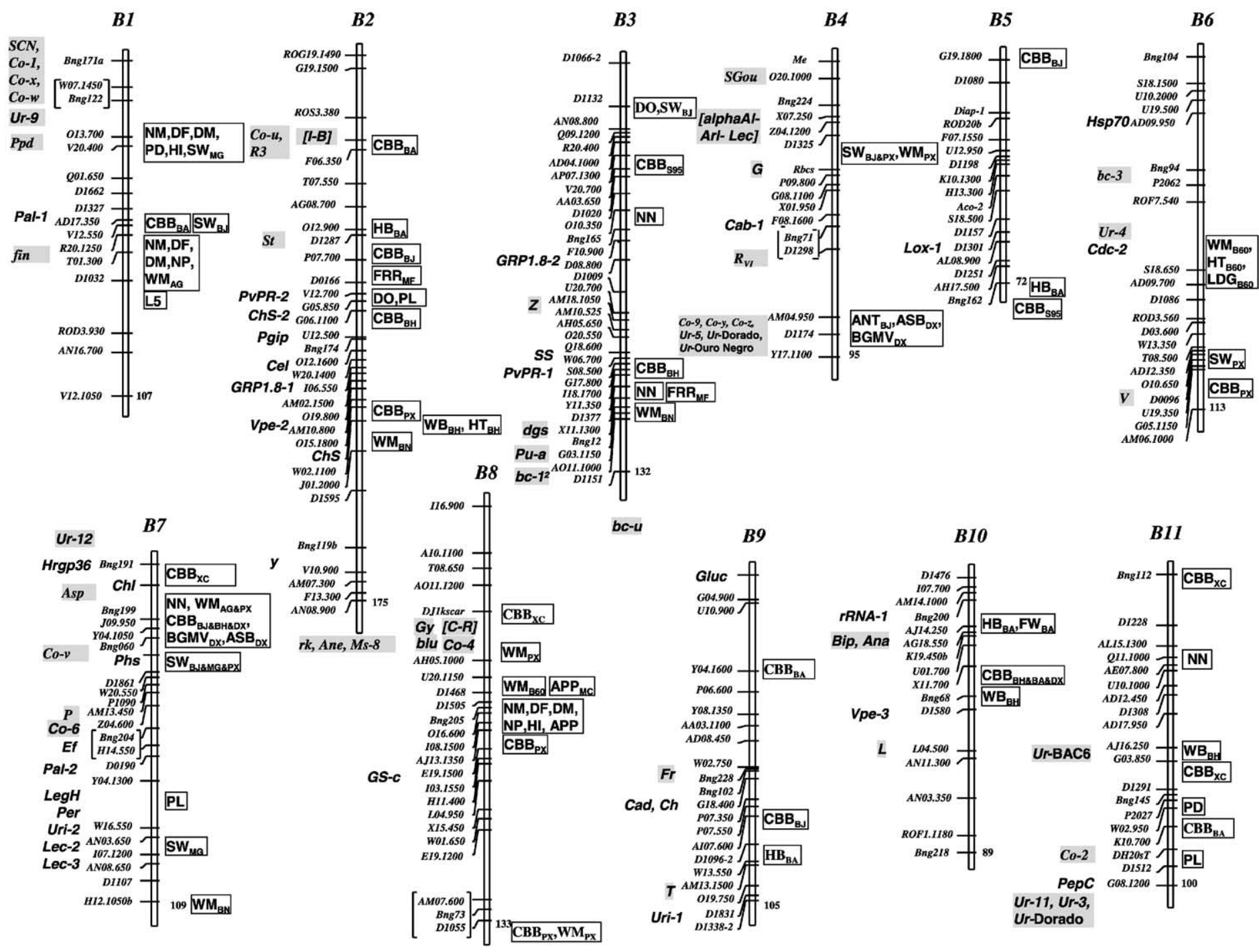


derived from corresponding RAPD markers were developed and have become the basis for the indirect selection of economically valuable traits in bean (Kelly and Miklas, 1998). As an extension of the initial single gene tagging experiments, linkages between markers and QTL controlling complex traits such as stress tolerance (Schneider et al., 1997) and complex disease resistance (Nodari et al., 1993b; Park et al., 2001; Table 1) have also been identified.

Fig. 1. Genomic distribution of genes with a biochemical function (mostly disease response genes), major genes coding for external phenotypic traits, and QTL in bean. Each LG is represented by its core map version (Freyre et al., 1998). To the left of each LG, are the framework molecular markers (smaller font) and the biochemical genes (larger font) and major phenotypic trait genes (shaded boxes). For explanations on marker and biochemical gene symbols (Bassett, 1996; Tables 4 and 5 in Gepts, 1999), and the original map references (Vallejos et al., 1992; Nodari et al., 1993a; AdamBlondon et al., 1994). The $C o$ and $R_{V I}$ loci are anthracnose resistance loci (Geffroy, 1997; Geffroy et al., 1999, 2000; Kelly and Young, 1996; Young et al., 1998; Vallejo and Kelly, 2002). The $U r$ loci are rust resistance loci (Kelly et al., 1996; Miklas et al., 2002b) including the $P u-a$ for abaxial leaf pubescence (Jung et al., 1998). $R 3$ is a resistance locus to bacterial brown spot (Crute and Pink, 1996). $b c-1^{2}$ and $b c-3$ are recessive genes for resistance to BCMV and $I$ is a dominant resistance to the same virus (Nodari et al., 1993a; Johnson et al., 1997; Miklas et al., 2000a,b; Melotto et al., 1996). [AI-Arl-Lec] is the main locus coding for the amylase inhibitor-arcelin-lectin multigene family. The fin, $P p d, S t$ are genes for determinacy, sensitivity to photoperiod, and pod string formation (Koinange et al., 1996). B, [C-R], $G, P$, and $r k$ are seed color genes and Ana, Ane, Bip, $L, T$ and $Z$ are seed color pattern genes (McClean et al., 2002). Asp is a gene for seedcoat shininess (Arndt and Gepts, 1989; Gepts, 1999). Recessive blu is a gene for blue flower color, and the $d g s$ gene conditions the dark green savoy leaf trait (Beltrán et al., 2002). $\mathrm{Fr}$ is a male fertility restorer gene (He et al., 1995). SGou and $M s-8$ are genes controlling pod cross-section and male sterility (Adam-Blondon et al., 1994). To the right (boxed symbols), are QTL mapped in different populations (Table 1)—ANT: anthracnose; APP: appearance of canned kidney beans; ASB: ashy stem blight; BGMV: bean golden mosaic virus; $\mathrm{CBB}$ : common bacterial blight resistance; DF and DM: number of days to flowering and to maturity; DO: seed dormancy; FRR: Fusarium root rot; FW: Fusarium wilt; HB: halo blight; HI: harvest index; HT: height; L5: length of the 5th internode; LDG: lodging; NM: number of nodes on the main stem; NN: Rhizobium nodulation; NP: number of pods; PD: photoperiodinduced delay in flowering; PL: pod length; SW: seed weight; WB: web blight; WM: white mold. SCN is the putative bean genome location of a soybean cyst nematode resistance gene mapped in part by synteny of bean RFLP probes in soybean (Concibido et al., 1996). Location of most genes is approximate, as most were not directly mapped in the BAT93/Jalo EEP558 population. The total distance of each LG (expressed in Kosambi cM) is shown at the right of the location of the bottom marker of that LG.
The choice to tag specific disease resistance loci was based on their relative availability and their importance in conferring resistance to major bean pathogens. Direct disease screening is not always desirable for reasons such as the lack of routine screening methods and informative races for discriminating specific resistance genes, quarantine restrictions, host escapes, or the inability to identify specific gene or gene combinations due to the occurrence of race or pathogen mixtures in the field. When screening conditions are not ideal, indirect selection of racespecific genes offers breeders a viable alternative to ensure that favorable gene combinations are present in new breeding lines. Markers, tightly linked to individual race-specific resistance genes, form the basis for effective indirect selection of major gene resistance. A list of markers linked to different genes conditioning resistance to seven pathogens of bean was published previously (Kelly and Miklas, 1998). The discovery of tightly linked markers now affords bean breeders the opportunity to pyramid resistance genes to effect more durable disease resistance to highly variable pathogens. Given the constant changes in pathogen populations in different environments, the value of previously defeated resistance genes cannot be underestimated in resistance breeding. MAS offers the only practical method to maintain such genes in current cultivars, since they are masked by the epistatic interactions of other resistance genes. Natural gene pyramids in landrace bean cultivars are known to be effective against the extensive pathogenic variability of Colletotrichum lindemuthianum (causal organism of bean anthracnose) (Balardin et al., 1997). For instance, the most resistant differential cultivar, G2333, a landrace named Colorado de Teopisca from Chiapas, Mexico, with resistance to 380 isolates of $C$. lindemuthianum (Pastor-Corrales et al., 1994), was found to possess three independent dominant genes $\left(\mathrm{Co}-4^{2}, \mathrm{Co}-5, \mathrm{Co}\right.$ 7; Young et al., 1998). The use of linked markers and their potential role in MAS for disease resistance to facilitate the efficient pyramiding of epistatic resistance genes for different pathogens of bean will be discussed in this article.

\subsection{Anthracnose}

Over 10 major genes conditioning resistance to anthracnose have been characterized and markers 
linked to six independent dominant genes ( $\mathrm{Co}-\mathrm{l}, \mathrm{Co}-2$, $\mathrm{Co}-4^{2}, \mathrm{Co}-5, \mathrm{Co}-6, \mathrm{Co}-9$ ) have been identified (Geffroy et al., 1999; Mendoza et al., 2000; Vallejo and Kelly, 2001, 2002; Young and Kelly, 1996a, 1997; Young et al., 1998). In addition to genetic studies that showed resistance to anthracnose resides at multiallelic loci (Melotto and Kelly, 2000; Young et al., 1998), mapping studies have confirmed that these loci reside on different LGs of the core bean map (Freyre et al., 1998). The Co-1 locus is located on LG B1; Co-2 on B11; Co-4 on B8; Co-6 on B7; and Co-9 on B4 (Geffroy et al., 1999; Gepts, 1999; Miklas et al., 2000a; J. Kelly, unpublished results; Fig. 1). Pyramiding genetically diverse resistance genes using MAS and deploying different gene combinations in different geographic regions is proposed as the most practical and realistic approach to provide efficient long-term control of bean anthracnose in a relatively short time period (Balardin and Kelly, 1998). Bean breeders have a unique opportunity to improve on natural gene pyramids in landrace cultivars by combining resistance genes from the two major gene pools to develop complementary resistance to a wide range of pathogenic races. For example, Young and Kelly (1996b) showed that the Andean Co-1 gene has a different resistance spectrum against races of $C$. lindemuthianum than the Middle American Co-2 gene. Highly virulent $C$. lindemuthianum races (1473 and 1572) of Middle American origin have been observed to be avirulent to genotypes carrying the Andean Co- 1 gene (Balardin et al., 1997; Pastor-Corrales et al., 1994, 1995; Young and Kelly, 1996b). Combining the Andean Co-1 gene, although defeated in many Andean countries, with the Middle American genes $\left(\mathrm{Co}-2, \mathrm{Co}-4^{2}, \mathrm{Co}-5\right.$ and $\left.\mathrm{Co}-6\right)$ would be the best strategy to develop complementary resistance to the predominant Middle American races of the pathogen present in Central America (Young and Kelly, 1997).

Since multiple alleles exist at the Co- $1, \mathrm{Co}-3$, and Co-4 loci (Melotto et al., 2000), the choice of the most effective allele is important in resistance breeding. The $C o-I^{2}$ allele in Kaboon has been under-utilized in breeding for anthracnose resistance because of associated inferior plant type, but using markerassisted-backcrossing the $\mathrm{Co}-\mathrm{I}^{2}$ allele can now be introgressed in Middle American germplasm, which would otherwise not be possible under local field selection because of the presence of multiple races of the pathogen. In the absence of virulent races of the pathogen and quarantine restrictions, Miklas and Kelly (2002a) used the SAS13 marker (Young et al., 1998) to backcross the $\mathrm{Co}-4^{2}$ allele into highly susceptible Durango race pinto beans grown widely in North America. When selecting for resistance in a particular region, the breeder should carefully choose a gene pair that, if deployed singly, would confer resistance to all known races in that region. In North America, this would be accomplished by combining the $\mathrm{Co}-4^{2}, \mathrm{Co}-5$ and $\mathrm{Co}-6$ genes, whereas for areas of Central America the most suitable gene pair would be the $\mathrm{Co}-\mathrm{I}^{2}$ and $\mathrm{Co}-4^{2}$ gene combination. Since the $\mathrm{Co}-4^{2}$ is recognized as the most broadly-based resistance gene (Awale and Kelly, 2001; Balardin and Kelly, 1998; Melotto and Kelly, 2001; Young et al., 1998), it would be invaluable in gene pyramids with other Middle American genes in those countries like the Dominican Republic and Ecuador where Andean races prevail. Finally, markers tightly linked to the $\mathrm{Co}-4^{2}$ and $\mathrm{Co}-5$ genes have been used successfully to identify a third independent gene ( $\mathrm{Co}-7)$ in the natural gene pyramids present in the highly resistant cultivars G2333 and G2338 (Young et al., 1998; J. Kelly, unpublished results).

\subsection{BCMV and bean common mosaic necrosis virus (BCMNV)}

Resistance to BCMV in bean is also conditioned by a series of multi-allelic loci (Drijfhout, 1978). The dominant $I$ gene, located on B2 (Gepts, 1999), is independent of three recessive $b c$ loci that are currently mapped. The $b c-3$ gene is located on B6 (Johnson et al., 1997; Gepts, 1999; Miklas et al., 2000a; Fig. 1), whereas the $b c-1^{2}$ allele resides on B3 (Miklas et al., 2000b). The non-specific $b c-u$ allele also resides on B3 based on the loose linkage with the $b c-1$ locus (Strausbaugh et al., 1999). The loose linkage is actually useful to breeders as the $b c-u$ is required for full expression of resistance of many of the race-specific $b c$ genes (Drijfhout, 1978; Kelly et al., 1995). The independence of the BCMV resistance genes provides opportunities to use gene pyramiding as a strategy in breeding for durable resistance. Bean breeders recognize that the combination of the dominant $I$ gene with recessive $b c$ resistance genes offers durability over single gene resistance to $\mathrm{BCMV}$ and $\mathrm{BCMNV}$ since 
the two types of genes have distinctly different mechanisms of resistance (Kelly, 1997; Kelly et al., 1995). The dominant $I$ gene is a resistance gene that confers a typical hypersensitive resistance, whereas the three most effective recessive genes $\left(b c-1^{2}, b c-2^{2}\right.$, $b c-3)$ act by restricting virus movement within the plant, probably by restricting the virus movement proteins (Kelly, 1997). The action of the dominant $I$ gene is masked by the recessive $b c-3$ gene, so as efforts to incorporate the $b c-3$ gene into new germplasm proceed, the risk of losing the $I$ gene in improved germplasm increases, since direct selection for the $I$ gene is not possible. Linked markers offer the only realistic opportunity to maintain and continue to utilize the $I$ gene as a pyramided resistance gene in future bean cultivars. A marker tightly linked to the $I$ gene, has been identified (Haley et al., 1994b; Melotto et al., 1996) and has been demonstrated in many labs to be effective across a wide range of germplasm from both gene pools. Breeders (Miklas et al., 1997, 2002a; Miklas and Kelly, 2002b) have used markers linked to the $I$ gene to develop enhanced germplasm with the $I+b c-3$ gene combination.

Conversely, selection against the unprotected $I$ gene may be advantageous in bean germplasm grown in east Africa where strains of BCMNV exist (Silbernagel et al., 1986) or in Central America where strains of bean severe mosaic virus (BSMV) occur (Morales and Castaño, 1992). Since the $I$ gene has been incorporated into a broad array of germplasm and is highly sensitive (resulting in plant death) to both BCMNV and BSMV, it poses an unacceptable risk to producers in both regions. Markers linked to the $I$ gene have been utilized to select against the $I$ gene while maintaining the BCMNV resistance afforded by the $b c-3$ gene in countries where the $I$ gene is undesirable. This strategy was used to develop a BCMNV resistant red bean for Central America that does not possess the $I$ gene (Beaver et al., 1998). However, caution must be used when deploying the $b c-3$ gene singly because some lines with putative $b c-3$ resistance have been observed to be susceptible to several common strains of BCMV (Miklas et al., 1998a).

Markers linked to the other resistance genes such as the $b c-u, b c-2^{2}$ and $b c-3$ genes are needed to facilitate their introgression and gene pyramiding into germplasm possessing the $I$ gene. In the case of the $b c-3$ gene, markers would be useful since bean breeders may not want to import strains of BCMNV for purposes of direct testing. Markers linked to the $b c-3$ gene have been identified (Haley et al., 1994a; Johnson et al., 1997), but these markers have not proven to be useful in a wide array of germplasm and have received limited usage. Direct screening with strains of BCMNV is still required to confirm the presence of the $b c-3$ gene. A marker tightly linked to the $b c-1^{2}$ gene (Miklas et al., 2000b) offers the best opportunity to develop pyramided resistance to diverse strains of BCMV and BCMNV in combination with the $I$ gene (Kelly et al., 1995). Clearly, gene pyramiding is a workable strategy in breeding for resistance to BCMV as the different resistance genes reside on different bean LGs (Fig. 1).

\subsection{Bean golden mosaic virus (BGMV)}

One of the disease problems where CRSP researchers have made the most significant impact in a relatively short time period has been the characterization of new sources of resistance to BGMV (Beaver et al., 2003). BGMV is a whitefly-transmitted geminivirus that was negatively impacting bean production throughout the Caribbean and Central America and existing resistance sources in P. vulgaris were inadequate to effectively control the disease in commercial bean production fields. CRSP researchers identified a source of partial resistance conditioned by the recessive bgm-1 gene derived from 'Garrapato' (Blair and Beaver, 1993). The source was characterized by a lack of mosaic symptom development, but showed pod deformation and reduced yield under moderate to severe disease pressure. To counter the loss of pod quality and yield, the recessive $b g m-1$ gene should be combined with other resistance genes conditioning non-deformed pods (Molina Castenado and Beaver, 1998), and the bgm-2 for reduced mosaic symptoms (Velez et al., 1998). To assist breeders, a codominant RAPD marker tightly linked with bgm- 1 was identified (Urrea et al., 1996) and is being used by public and private breeders to hasten the development of bean germplasm for the Caribbean and Central America and snap bean germplasm with moderate levels of BGMV resistance for southern Florida (McMillan et al., 1998; Stavely et al., 1997). The pole garden bean cultivar Genuine (Shamrock Seed, Salinas, CA), with moderate resistance to BGMV, is a result of MAS 
Table 2

Putative clusters of disease and pest resistance genes and QTL in bean ${ }^{\mathrm{a}}$

\begin{tabular}{|c|c|c|c|c|c|}
\hline LG & $\begin{array}{l}\text { Putative } \\
\text { cluster number }\end{array}$ & $\begin{array}{l}\text { Linked markers } \\
\text { (RFLPs or SCARs) }\end{array}$ & $\begin{array}{l}\text { Linked disease } \\
\text { response genes }\end{array}$ & Major genes & Quantitative trait loci \\
\hline \multirow[t]{2}{*}{$\mathrm{B} 1$} & 1 & Bng171a, Bng122 & & $\begin{array}{l}\text { Co-1, Co- } x, \text { Co-w; } \\
\text { Ur- } 9 ; \text { SCN (soybean) }\end{array}$ & \\
\hline & 2 & D1032, D1315, D1327 & Pal-1 & & $\mathrm{CBB}_{\mathrm{BA}}, \mathrm{WM}_{\mathrm{AG}}$ \\
\hline \multirow[t]{3}{*}{ B2 } & 1 & SW13 & & $I, R 3$, Со- $u$ & $\mathrm{CBB}_{\mathrm{BA}}$ \\
\hline & 2 & $D 1287, D 0166$ & $\begin{array}{l}P v P R-2, \\
C h S-2, \text { Pgip }\end{array}$ & & $\mathrm{CBB}_{\mathrm{BJ}}, \mathrm{CBB}_{\mathrm{BH}}, \mathrm{FRR}_{\mathrm{MF}}, \mathrm{HB}_{\mathrm{BA}}$ \\
\hline & 3 & & ChS, Vpe-2 & & $\mathrm{CBB}_{\mathrm{PX}}, \mathrm{WB}_{\mathrm{BH}}, \mathrm{WM}_{\mathrm{BN}}$ \\
\hline B3 & 1 & D1377 & $P v P R-1$ & & $\mathrm{CBB}_{\mathrm{BH}}, \mathrm{FRR}_{\mathrm{MF}}, \mathrm{WM}_{\mathrm{BN}}, \mathrm{NN}$ \\
\hline B4 & 1 & $D 1174$ & & $\begin{array}{l}\text { Co-9, Co-y, Co-z, Ur-5, } \\
U r \text {-Dorado, Ur-Ouro Negro }\end{array}$ & $\mathrm{ANT}_{\mathrm{BJ}}, \mathrm{ASB}_{\mathrm{DX}}, \mathrm{BGMV}_{\mathrm{DX}}$ \\
\hline B5 & 1 & Bng162 & & & $\mathrm{CBB}_{\mathrm{S} 95}, \mathrm{HB}_{\mathrm{BA}}$ \\
\hline B7 & 1 & $\begin{array}{l}\text { D1861, Phs, } \\
\text { Bng060, Bng199 }\end{array}$ & $C h I$ & Co-v & $\begin{array}{l}\mathrm{ASB}_{\mathrm{DX}}, \mathrm{BGMV}_{\mathrm{DX}}, \\
\mathrm{CBB}_{\mathrm{BH}}, \mathrm{BJ}, \mathrm{DH}, \mathrm{NN}, \mathrm{WM}_{\mathrm{AG}, \mathrm{PX}}\end{array}$ \\
\hline $\mathrm{B} 8$ & $\begin{array}{l}1 \\
2 \\
3\end{array}$ & $\begin{array}{l}\text { SAS13, DJ1kscar } \\
\text { D1505, Bng205 } \\
\text { D1055 }\end{array}$ & & Co-4 & $\begin{array}{l}\mathrm{CBB}_{\mathrm{XC}}, \mathrm{WM}_{\mathrm{PX}} \\
\mathrm{CBB}_{\mathrm{PX}}, \mathrm{WM}_{\mathrm{B} 60} \\
\mathrm{CBB}_{\mathrm{PX}}, \mathrm{WM}_{\mathrm{PX}}\end{array}$ \\
\hline B10 & 1 & Bng200, Bng68 & & & $\mathrm{CBB}_{\mathrm{DX}}, \mathrm{HB}_{\mathrm{BA}}, \mathrm{FW}_{\mathrm{BA}}, \mathrm{WB}_{\mathrm{BH}}$ \\
\hline B11 & $\begin{array}{l}1 \\
2\end{array}$ & $\begin{array}{l}D 1308, D 1291 \\
D 1512\end{array}$ & & $\begin{array}{l}U r \text {-BAC6 } \\
\text { Co-2,Ur-3,Ur-11,Ur-Dorado }\end{array}$ & $\begin{array}{l}\mathrm{WB}_{\mathrm{BH}}, \mathrm{CBB}_{\mathrm{XC}} \\
\mathrm{CBB}_{\mathrm{BA}}\end{array}$ \\
\hline
\end{tabular}

${ }^{\mathrm{a}}$ Abbreviations are same as in Fig. 1.

for the bgm-1 marker. The marker for bgm-1 is independent of gene pools, so a SCAR marker linked to the resistance band was developed at Centro Internacional de Agricultura Tropical (CIAT) to facilitate its use through PCR multiplexing. The SCAR is being extensively employed by scientists at CIAT to ensure that the bgm-l gene is present in all new bean germplasm targeted for production in Central America.

In addition to the resistance conditioned by major genes, two independent QTL were identified as having a major effect on the reduced mosaic resistance trait in the cultivar Dorado (Miklas et al., 1996). Together, these two QTL explained $60 \%$ of the phenotypic variation in BGMV reaction for one environment, and were consistently expressed across three separate field environments where the pathogen was present. One of the QTL is located on B4 based on the presence of a SCAR marker developed from the RAPD OW12 700 marker (Miklas et al., 1996, 2000a). The location was confirmed in a second mapping population developed at CIAT, where Dorado was a common parent. The QTL on B4 was negatively associated with resistance to Macrophomina phaseolina present in the second parent (XAN176) of the mapping population (Miklas et al., 2000a). The second QTL for BGMV resides on B7, near the Asp and Phs loci where QTL or major genes conditioning resistance to common bacterial blight (CBB), white mold (causal organism Sclerotinia sclerotiorum), anthracnose, and Macrophomina were also detected (Nodari et al., 1993b; Geffroy, 1997; Miklas et al., 2000a, 2001a; Table 2). The markers for bgm-1 and the QTL on B4 cosegregated with BGMV resistance in advanced lines derived from multi-parent crosses conducted by CIAT (Singh et al., 2000). Since the reduced mosaic resistance of Dorado is conditioned by few QTL, with intermediate to major effect, a marker-assisted-backcross program may be the most effective way to combine these resistance traits with the resistance conferred by the bgm genes.

\subsection{Bean rust}

The pyramiding of different resistance genes and mechanisms (specific, adult plant, slow rusting, 
reduced pustule size, and pubescence) will likely prolong the life of a bean cultivar by creating a more durable resistance complex against the highly variable rust pathogen, Uromyces appendiculatus (Jung et al., 1998; Mmbaga et al., 1996). Since screening for specific rust resistance in the field or greenhouse is relatively easy, use of informative races to detect epistatic genes should be more efficient, but often discriminating races are unavailable or are too risky to use outside their zone of occurrence. Alternatively, markers have been useful for maintaining hypostatic rust resistance genes in the presence of epistatic resistance genes. For instance, in the development of the rust resistant navy bean lines BelMiDak-RR1 to -7 , Stavely et al. (1994) used a marker linked to the $U r-4$ gene (Miklas et al., 1993) to verify its presence in combination with the $U r-11$ gene (Stavely, 1998). The $U r-4$ gene was the first resistance gene tagged in bean (Miklas et al., 1993), and represented the use of NILs and DNA bulking procedures prior to the publication of the BSA protocol of Michelmore et al. (1991).

In addition to the $U r-4$ gene, six other rust resistance genes, $U r-3, U r-5, U r-7, U r-9, U r-11$, and $U r-12$ and three unnamed genes, one in BAC6 (Jung et al., 1996a,b) and two in Dorado (Miklas et al., 2000a), have been tagged (Haley et al., 1993, 1994c; Johnson et al., 1995; Jung et al., 1998; Kelly et al., 1996; Park et al., 1999a,b). The utility of the markers for indirect selection of the $U r-3$ and $U r-11$ genes (Boone et al., 1999; Haley et al., 1994c; Johnson et al., 1995) has not been validated so their use has been limited. Two genes that are under-utilized in breeding for rust resistance are the $U r-5$ (Haley et al., 1993) and Ur-9 (Jung et al., 1998) genes. A SCAR marker is available for the $U r-5$ gene (Melotto and Kelly, 1998), and the $U r-9$ represents a useful Andean source that would complement the many Middle American genes that condition resistance to limited numbers of rust races.

The importance of gene pyramids for rust resistance was recently observed in Honduras. Bean lines carrying the broadly effective $U r-11$ resistance gene, derived from PI 181996 (Stavely, 1990), were infected by a newly identified rust pathotype (race 108) (Stavely et al., 1997), whereas lines possessing either the hypostatic $U r-4$ or $U r-5$ resistance gene in addition to $U r$ - 11 were not infected (Mmbaga et al., 1996).
The importance of previously defeated resistance genes in gene pyramids should not be underestimated. When several genes are to be pyramided using MAS, Beaver and Macchiavelli (1998) suggested waiting until the $\mathrm{F}_{4}$ generation to screen for linked markers. Screening in the $\mathrm{F}_{4}$ would improve the probability of identifying lines with the desired genotype and would drastically reduce the minimum number of lines that need to be evaluated.

Based on the location of all known rust resistance genes in the bean genome, more clustering is apparent among rust resistance genes when compared with resistance genes for anthracnose and BCMV (Fig. 1). Unnamed genes from Dorado and Ouro Negro (Corrêa et al., 2000) map near Ur-5 on LG B4 (Miklas et al., 2000a,b). The Ur-3 and Ur-11 genes (Miklas et al., $2002 \mathrm{~b}$ ) and an unnamed rust resistance gene from Dorado (Miklas et al., 2000a) map toward the end of B11, distally located from the Co-2 locus. The unnamed rust resistance gene from BAC6 also resides on $\mathrm{B} 11$ as determined by RAPD markers common among the BJ (Gepts, 1999), A55 × BelNeb-RR-1 (Ariyarathne et al., 1999), and BAC6 $\times$ HT7719 (Jung et al., 1996b; Park et al., 1999b) mapping populations (Table 2). However, the BAC6 gene does not appear to be linked with the unnamed resistance gene from Dorado, or the $U r-3$ and $U r-11$ loci on B11 (Miklas et al., 2002b). The $U r-4(U p-2)$ gene now resides on B6 (Miklas et al., 2002b) not B4 as previously mapped (Gepts et al., 1993). Among the other rust resistance genes, $U r-9$ maps to B1 and $U r-12$ for adult plant resistance maps to B7 (Jung et al., 1998; Miklas et al., 2002b; Park et al., 1999a).

Traditional phenotypic disease reaction data also indicated that $U r-11$ was linked in repulsion with the $U r-3$ gene (Stavely, 1998). That linkage, however, has successfully been broken and breeding lines were developed with both genes combined in coupling (Stavely, 2000). Additional genetic evidence supports that $U r-4$ and $U r-5$ are independent of each other and of $U r-3$ and $U r-11$ (Kelly et al., 1996), and $U r-4$ is independent of $U r-6$ (Stavely and Kelly, 1996). The $U r-4$ and $U r-5$ genes have been successfully combined in the BARC-rust resistant green and wax bean germplasm lines (Stavely and Steinke, 1990; Stavely and McMillan, 1992).

In the absence of mapping data on other rust genes, the existence of gene clusters appears to be more 
common for rust than for anthracnose resistance genes in bean. For instance, Stavely (1984) showed that resistance to individual rust races in the bean line B-190 (Ur-5 gene) is conditioned by single dominant genes linked in coupling that appear to be inherited as a complex linkage block. The apparent linkage of additional unnamed genes from Dorado and Ouro Negro suggests that the $U r-5$ genomic region may contain an even greater complex of linked genes than previously considered. The data suggest that rather than applying one model for all pathosystems, bean breeders need to recognize that differences do exist and strategies in resistance breeding should accommodate these differences. More data are needed on the map location of all rust resistance genes to assist in the effort of pyramiding resistance as too much emphasis is being placed on the use of the single $U r-3$ gene in North America despite the multigene pyramids available in breeding lines in three major US commercial bean seed classes (Pastor-Corrales et al., 2001; Stavely et al., 1992, 1994, 1997).

\subsection{Common bacterial blight}

The discovery of markers linked to $\mathrm{CBB}$, in bean has revolutionized our understanding of resistance to $\mathrm{CBB}$, caused by Xanthomonas axonopodis pv. phaseoli (Xap). The identification, by CRSP scientists, of different QTL conditioning resistance in young and adult tissues (Miklas et al., 1996), and of one genomic region possessing a factor(s) which influenced resistance in all three tissues, seeds, leaves, and pods, while another QTL only influenced resistance within a single plant organ (Jung et al., 1997), has helped to simplify an obvious complex situation. Five QTL conferring resistance to Xap were identified by Nodari et al. (1993b) with four of them located on LGs B2, B5, B7, and B9 in the BJ population. Only one QTL on B7 was common with four additional QTL that reside on LGs B6-B8 and B10 (Miklas et al., 2000c; Fig. 1 and Table 2). Given the paucity of resistance in $P$. vulgaris the QTL on B6-B8 and B10 were previously considered to be derived from the tepary bean, P. acutifolius. Recent evidence (Miklas et al., 2003), however, suggests that only the two QTL on B6 and B8 derive from tepary bean. The QTL for resistance on B10 originated from the great northern bean line GN Nebraska No. 1 sel. 27 (Coyne and Schuster, 1974), which resulted from the interspecific cross Montana no. $5 \times$ tepary no. 4 (Honma, 1956), thus the QTL was considered to be of tepary origin. The absence of SAP6 and BC409 markers (Miklas et al., 2000a; Jung et al., 1999) in P. acutifolius accessions, combined with the cosegregation of SAP6 with Xap resistance in a Montana no. $5 \times$ othello population, suggests that the QTL on B10 comes from the common bean cultivar Montana no. 5 (Miklas et al., 2003). The value, however, of both B10 markers in MAS may be limited to Andean germplasm, as many susceptible Middle American genotypes possess both markers (Miklas et al., 2003; J. Kelly, unpublished results). The origin of the QTL located on B7 near the Phs locus is not fully understood, but it likely derives from either GN Nebraska no. 1 sel. 27 or PI 207262. This QTL has been identified in three independent studies (Jung et al., 1999; Miklas et al., 1996; Nodari et al., 1993b), but no SCAR marker linked to this QTL has yet been developed for purposes of indirect selection.

The QTL derived from tepary bean are located on B6 and B8 (Miklas et al., 2000c). The BC420 marker (Yu et al., 2000a) linked to a major QTL from XAN159 is located on B6 near the $V$ locus that conditions purple flower color (Jung et al., 1997). Tightly linked to the QTL on B8 were the SU91 marker from XAN159 (Jung et al., 1998; Pedraza et al., 1997) and R7313 from OAC-88-1 (Bai et al., 1997). Interestingly, the SU91 marker present in the bean lines XAN159 and SEL1309 was derived from the tepary PI 319433, whereas the tightly linked R7313 marker in OAC-88-1 came from the tepary PI 440795 (Scott and Michaels, 1992) suggesting that both tepary accessions carried the same resistance source.

Given the substantial efforts to generate interspecific hybrids between $P$. vulgaris and P. acutifolius, the potential of markers in assisting future bean breeders to distinguish between resistance loci cannot be overemphasized. The combination of resistance QTL, as in the pyramiding of qualitative genes, should contribute to more effective and durable CBB resistance. Bean breeders now have the tools to combine distinct resistance sources for CBB from common and tepary bean sources to effect greater levels of resistance in new bean cultivars. Markers have been invaluable in helping to elucidate the type and nature of resistance to Xap and now provide the tools for effective MAS to 
proceed. CRSP scientists are backcrossing the major independent QTL from resistance into snap bean and all the major US dry bean market classes using the SU91, BC420, and SAP6 markers. Evidence for effective MAS of these QTL, outside the original mapping populations, has been repeatedly demonstrated by other researchers (Fourie and Herselman, 2002; Jung et al., 1999; Miklas et al., 2000c, 2003; Mutlu et al., 2002; Park et al., 1999c; Yu et al., 2000a).

\subsection{Yield and phenology}

The divergence between the Andean and the Middle American gene pools constitutes both an opportunity for breeders to broaden the genetic basis of bean classes and a challenge to actually transfer quantitative traits from one gene pool to the other. Generally, the success rate has been quite low (Welsh et al., 1995; Johnson and Gepts, 1999), but there are exceptions to this pattern (Beaver and Kelly, 1994). In order to investigate the cause of these difficulties, the segregation of yield-related traits was studied in a recombinant inbred population resulting from a cross between an Andean (California Dark Red Kidney) and a Middle American (Yolano Pink) cultivar. Concurrently, a molecular linkage map was established in this population and a QTL analysis was conducted for the following traits: seed yield per day, biomass per day, number of days to maturity, and harvest index. Seed yield and biomass were analyzed on a per day basis to attempt to eliminate the effect of cycle length. It was hypothesized that divergence between the Andean and Middle American gene pools would have led to epistatic gene interactions characteristic of each gene pool and leading to higher yield in each of these gene pools. Hybridization between these gene pools would break up these interactions, which in turn would lead to inferior performance. The QTL analyses showed that epistatic interactions were indeed important in determining yield. However, the parental combination of alleles at different loci (A-A or $\mathrm{M}-\mathrm{M})$ did not always lead to superior performance but recombinant combinations (A-M) could also be advantageous (Johnson and Gepts, in press). These results suggested that the outbreeding depression shown by Andean $\times$ Middle American crosses was due to the fact that yield and related traits such as harvest index are controlled by a large suite of genes that is easily disrupted by recombination in the progeny of crosses. They also suggest, however, that with the appropriate breeding method superior suites of genes leading to high yield can be developed in Andean $\times$ Middle American crosses.

\section{Linkages between disease resistance traits in bean}

Since linkages between traits are not uncommon, both coupling and repulsion linkages have been reported between markers associated with disease resistance traits in bean (Haley et al., 1994a). A repulsion linkage between QTL affecting BGMV and $\mathrm{CBB}$ resistance was observed on LG B7, which partially explained the low, but consistent, negative phenotypic correlation $(r=-0.23)$ observed between those two traits in the Dorado $\times$ XAN176 population (Miklas et al., 1996). Ur-5, unnamed rust resistance genes from Dorado and Ouro Negro (Corrêa et al., 2000), Co-9 and Co-10 (Geffroy et al., 1999; AlzateMarin et al., 2003), and QTL conditioning resistance to BGMV and Macrophomina all map to a common region on B4 (Miklas et al., 2000a, 2002b; Fig. 1 and Table 2). An unknown gene for rust resistance from Dorado, $U r-3, U r-11$, and $\mathrm{Co}-2$ are linked on B11 (Miklas et al., 2000a, 2002b; Fig. 1 and Table 2). The gene for small pustule rust resistance mapped near a region influencing web blight resistance (Jung et al., 1996a) in the BAC6 $\times$ HT7719 population. Another association between web blight and CBB resistance with the RAPD marker $B C 409_{1250}$ was reported by Jung et al. (1996a), but the marker was not mapped in the same population. QTL for resistance to halo blight (Psuedomonas syringae pv. phaseolicola) and Fusarium wilt (Fusarium oxysporum pv. phaseoli) are linked in repulsion on B10 (Fall et al., 2001), but they are not linked with the QTL for CBB resistance present on B10 LG (Ariyarathne et al., 1999). Located on B7, in a region that includes the phaseolin locus $P h s$ and Asp gene conditioning seed brilliance, is a QTL for CBB resistance (Nodari et al., 1993b; Jung et al., 1996a; Miklas et al., 1996, 2000a; Fig. 1). Recently, QTL for resistance to white mold (caused by S. sclerotiorum; Miklas et al., 2001a) and Macrophomina (Miklas et al., 1998b) have also been identified in the same general region. LG B7 was also 
identified as the site for white mold resistance in two other genetically distinct recombinant inbred populations (Park et al., 2001; Kolkman and Kelly, 2003). These linkages may represent the initial visualization of resistance gene clusters in bean (Miklas et al., 2000a; Geffroy et al., 1999, 2000) as has been observed in other crops (Tamulonis et al., 1997; Witsenboer et al., 1995). QTL controlling resistance to white mold and Fusarium root rot (caused by Fusarium solani pv. phaseoli) clustered on LGs B2 and $\mathrm{B} 3$ in the region of the Phaseolus vulgaris pathogenesis-related $(P \nu \mathrm{PR} 1$ and 2$)$ proteins (Kolkman and Kelly, 2003; Schneider et al., 2001; Fig. 1). Given that the $P v$ PR proteins are defense related proteins, enhancing their expression might offer opportunities to improve resistance to both complex soil-borne pathogens of bean. Two other major effect QTL conditioning white mold resistance, one for physiological resistance on $\mathrm{B} 8$ and another for avoidance resistance on B6 near the $A 14_{1100}$ RAPD linked with the $U r-4$ locus (Miklas et al., 1993), were mapped in a separate population by Miklas et al. (2001b). An additional QTL for avoidance conditioned by the fin gene is located on B1 (Miklas et al., 2001a; Table 2). QTL for abiotic stresses such as drought tolerance have been identified (Schneider et al., 1997) but lack widespread application to date.

From a breeder's perspective, linkages among resistance loci are beneficial when they are derived from an individual parental line (cis-configuration), because when crossed with susceptible parents these resistances will be inherited as a single unit and likely will remain intact in subsequent progeny (Geffroy et al., 1998). When linked resistance genes are donated by different parents (trans-configuration) recombination between the loci is necessary to obtain both resistance sources in a single line. For example, due to negative trans-linkages, recombination among QTL on B4 and B7 will be needed to combine parental levels of resistance to BGMV, CBB, and Macrophomina in the Dorado $\times$ XAN176 population (Miklas et al., 1996, 1998b, 2000a). Linkage between rust and anthracnose resistance loci on B1, B4 and B11 should facilitate simultaneous selection for resistance to both diseases (Table 2). Thus, breeding multiple disease resistant cultivars will be complicated initially by these trans-linkages, and subsequently simplified once the linked genes are recombined in cis-orientation. An appealing use for MAS would be the indirect selection of gene clusters using flanking markers.

\section{Summary}

Molecular markers should be used in bean and cowpea breeding for a variety of purposes in the future. These purposes include primarily disease and pest resistance, but also introgression of exotic germplasm, tolerance to abiotic stresses, and improvement of quality traits such as nutritional quality. With the identification of over 30 markers linked to 17 different resistance genes and QTL in P. vulgaris (Fig. 1 and Tables 1 and 2), the opportunity for MAS in disease resistance breeding in bean now exists. When costs are balanced against applications, bean breeders may choose to combine MAS with phenotypic selection as a practical alternative to selection for multiple traits. As additional markers are detected for other genes, the value of the technology will increase since MAS for more than one trait can be practiced in breeding populations. The value of MAS of quantitative traits will become more important and useful as phenotypic data and the technology for the detection of QTL improves. Additional markers will have to be PCR-based to facilitate their widespread use and automation. Since new marker technologies are moving away from electrophoresis to cut costs and increase throughput, focused efforts in bean and cowpea genomics will have to be organized to develop SSR and SNP markers to exploit genomic resources both as a source of high-throughput markers and as tools of marker analysis and gene discovery.

The direct incorporation of single gene resistance to the prevalent races of a pathogen within a particular area is currently the breeding method of choice, but this resistance is often short-lived, forcing breeders to continuously incorporate new resistance genes into their programs. Combining different genes with resistance to the prevalent races, although more difficult and expensive to achieve initially, should provide a more durable resistance for long-term protection. MAS provides opportunities to pyramid genes not feasible with traditional breeding methods. Genetic markers will likely be used in the development of future bean and cowpea cultivars possessing durable disease resistance. Along the same lines, it is probable 
that markers will be used to facilitate introgression of genetic diversity from exotic germplasm, including both wild and domesticated forms. Several strategies can be envisioned, including the simultaneous markerbased selection for genes of interest and against deleterious genes, and the introgression of genes for adaptation into exotic germplasm to allow their evaluation under temperate conditions. To be fully effective across a wide range of genetic backgrounds, the number of molecular markers in bean and cowpea will have to be increased substantially and other marker technologies will need to be exploited.

\section{Acknowledgements}

Research reported in this review was supported in part by the grant DAN 1310-G-SS-6008-00 from the USAID Bean/Cowpea Collaborative Research Support Program.

\section{References}

Adam-Blondon, A., Sévignac, M., Dron, M., 1994. A genetic map of common bean to localize specific resistance genes against anthracnose. Genome 37, 915-924.

Alzate-Marin, A.L., Costa, M.R., Arruda, K.M., de Barros, E.G., Moreira, M.A., 2003. Characterization of the anthracnose resistance locus present in cultivar Ouro Negro (Honduras 35). Euphytica (in press).

Ariyarathne, H.M., Coyne, D.P., Jung, G., Skroch, P.W., Vidaver, J.R., Steadman, A.K., Miklas, P.N., Bassett, M.J., 1999. Molecular mapping of disease resistance genes for halo blight, common bacterial blight, bean common mosaic virus in a segregating population of common bean. J. Am. Soc. Hort. Sci. 124, 654-662.

Arndt, G.C., Gepts, P., 1989. Segregation and linkage for morphological and biochemical markers in a wide cross in common bean (Phaseolus vulgaris). Annu. Rep. Bean Improv. Coop. 32, 68-69.

Awale, H.E., Kelly, J.D., 2001. Development of SCAR markers linked to $\mathrm{Co}-4^{2}$ gene in common bean. Annu. Rep. Bean Improv. Coop. 44, 119-120.

Bai, Y., Michaels, T.E., Pauls, K.P., 1997. Identification of RAPD markers linked to common bacterial blight resistance genes in Phaseolus vulgaris L. Genome 40, 544-551.

Balardin, R.S., Kelly, J.D., 1998. Interaction between races of Colletotrichum lindemuthianum and gene pool diversity in Phaseolus vulgaris. J. Am. Soc. Hort. Sci. 123, 1038-1047.

Balardin, R.S., Jarosz, A.M., Kelly, J.D., 1997. Virulence and molecular diversity in Colletotrichum lindemuthianum from
South, Central and North America, Central and North America. Phytopathology 87, 1184-1191.

Bassett, M.J., 1988. Linkage mapping of marker genes in common bean. In: Gepts, P. (Ed.), Genetic Resources of Phaseolus Beans. Kluwer Academic Publishers, Dordrecht, The Netherlands, pp. 329-353.

Bassett, M.J., 1991. A revised linkage map of common bean. HortScience 26, 834-836.

Bassett, M.J., 1996. List of genes-Phaseolus vulgaris L. Annu. Rep. Bean Improv. Coop. 39, 1-19.

Beaver, J.S., Kelly, J.D., 1994. Comparison of selection methods for dry bean populations derived from crosses between gene pools. Crop Sci. 34, 34-37.

Beaver, J.S., Macchiavelli, R., 1998. Breeding strategies for pyramiding genes for resistance. Annu. Rep. Bean Improv. Coop. 41, 141-142.

Beaver, J.S., Miklas, P.N., Kelly, J.D., Steadman, J.R., Rosas, J.C., 1998. Registration of PR9357-107 small red dry bean germplasm resistant to BCMV, BCMNV, and rust. Crop Sci. 38, 1408-1409.

Beaver, J.S., Rosas, J.C., Myers, J., Acosta, J., Kelly, J.D., Nchimbi-Msolla, S., Misangu, R., Bokosi, J., Temple, S., Coyne, D.P., 2003. Contributions of the bean/cowpea CRSP to cultivar and germplasm development in common bean. Field Crops Res. (companion article-in same FCR edition).

Beltrán, G.E., Jung, G., Nienhuis, J., Bassett, M.J., 2002. Identification of RAPD markers linked to five marker genes (blu, dgs, y, arg, and a flat pod mutant) in common bean. J. Am. Soc. Hort. Sci. 127, 685-688.

Beninger, C.W., Hosfield, G.L., Bassett, M.J., Owens, S., 2000. Chemical and morphological expression of the $B$ and Asp seedcoat genes in Phaseolus vulgaris. J. Am. Soc. Hort. Sci. 125, 52-58.

Blair, M.W., Beaver, J.S., 1993. Inheritance of BGMV resistance from bean genotype A429. Annu. Rep. Bean Improv. Coop. 36, 143.

Boone, W.E., Stavely, J.R., Weeden, N.F., 1999. Development of a sequence-tagged site (STS) marker for the Ur-11, a gene conferring resistance to bean rust fungus, Uromyces appendiculatus. Annu. Rep. Bean Improv. Coop. 42, 33-34.

Concibido, V., Young, N., Lange, D., Denny, R., Danesh, D., Orf, J., 1996. Targeted comparative genome analysis and qualitative mapping of a major partial-resistance gene to the soybean cyst nematode. Theoret. Appl. Genet. 93, 234-241.

Corrêa, R.X., Costa, M.R., Good-God, P.I., Ragagnin, V.A., Faleiro, F.G., Moreira, M.A., de Barros, E.G., 2000. Sequence characterized amplified regions linked to rust resistance genes in the common bean. Crop Sci. 40, 804-807.

Coyne, D.P., 1967. Photoperiodism: inheritance and linkage studies in Phaseolus vulgaris. J. Hered. 58, 313-314.

Coyne, D.P., Schuster, M.L., 1974. Breeding and genetic studies of tolerance to several bean (Phaseolus vulgaris) bacterial pathogens. Euphytica 231, 651-656.

Crute, I., Pink, D., 1996. Genetics and utilization of pathogen resistance in plants. Plant Cell 8, 1747-1755.

Delaney, D.E., Bliss, F.A., 1991a. Selection for increased percentage phaseolin in common bean. 1. Comparison of 
selection for seed protein alleles and S1 family recurrent selection. Theoret. Appl. Genet. 81, 301-305.

Delaney, D.E., Bliss, F.A., 1991b. Selection for increased percentage phaseolin in common bean. 2. Changes in frequency of seed protein alleles with $\mathrm{S} 1$ family recurrent selection. Theoret. Appl. Genet. 81, 306-311.

Drijfhout, E., 1978. Genetic interaction between Phaseolus vulgaris $\mathrm{L}$. and bean common mosaic virus with implications for strain identification and breeding for resistance. Agricultural Research Report No. 872. Centre for Agriculture Publishing and Documentation, Wageningen, The Netherlands, pp. 1-98.

Fall, A.L., Byrne, P.F., Jung, J., Coyne, D.P., Brick, M.A., Schwartz, H.F., 2001. Detection and mapping of a major locus for Fusarium wilt resistance in common bean. Crop Sci. 41, 1494-1498.

Fatokun, C.A., Menancio-Hautea, D.I., Danesh, D., Young, N.D., 1992. Evidence for orthologus seed weight genes in cowpea and mung bean based on RFLP mapping. Genetics 132, 841846.

Fatokun, C.A., Danesh, D., Menancio-Hautea, D.I., Young, N.D., 1993. A linkage map for cowpea (Vigna unguiculata (L.) Walp.) based on DNA markers. In: O'Brien, S.J. (Ed.), Genetic Maps, 6th ed. Cold Spring Harbor Laboratory Press, Cold Spring Harbor, NY, pp. 6.257-6.258.

Fourie, D., Herselman, L., 2002. Breeding for common blight resistance in dry beans in South Africa. Annu. Rep. Bean Improv. Coop. 45, 50-51.

Freyre, R., Skroch, P.W., Geffroy, V., Adam-Blondon, A.F., Shirmohamadali, A., Johnson, W.C., Llaca, V., Nodari, R.O., Pereira, P.A., Tsai, S.-M., Tohme, J., Dron, M., Nienhuis, J., Vallejos, C.E., Gepts, P., 1998. Towards an integrated linkage map of common bean. 4. Development of a core linkage map and alignment of RFLP maps. Theoret. Appl. Genet. 97, 847-856.

Geffroy, V., 1997. Dissection génétique de la résistance à Colletotrichum lindemuthianum, agent de l'anthracnose, chez deux génotypes représentatifs des pools géniques de Phaseolus vulgaris. Doctoral Thesis. Institut National Agronomique, Paris, Grignon.

Geffroy, V., Creusot, F., Falquet, J., Sévignac, M., Adam-Blondon, A.-F., Bannerot, H., Gepts, P., Dron, M., 1998. A family of LRR sequences in the vicinity of the $\mathrm{Co}-2$ locus for anthracnose resistance in Phaseolus vulgaris and its potential use in marker-assisted selection. Theoret. Appl. Genet. 96, 494-502.

Geffroy, V., Sicard, D., de Oliveira, J.C.F., Sévignac, M., Cohen, S., Gepts, P., Neema, C., Langin, T., Dron, M., 1999. Identification of an ancestral resistance gene cluster involved in the coevolution process between Phaseolus vulgaris and its fungal pathogen Colletotrichum lindemuthianum. Mol. Plant-Microb. Interact. 12, 774-782.

Geffroy, V., Sévignac, M., De Oliveira, J., Fouilloux, G., Skroch, P., Thoquet, P., Gepts, P., Langin, T., Dron, M., 2000. Inheritance of partial resistance against Colletotrichum lindemuthianum in Phaseolus vulgaris and co-localization of QTL with genes involved in specific resistance. Mol. Plant-Microb. Interact. 13, 287-296.
Gepts, P., 1988. Provisional linkage map of common bean. Annu. Rep. Bean Improv. Coop. 31, 20-25.

Gepts, P., 1998. Origin and evolution of common bean, past event and recent trends, past event and recent trends. HortScience 33, 1124-1130.

Gepts, P., 1999. Development of an integrated linkage map. In: Singh, S.P. (Ed.), Developments in Plant Breeding. Common Bean Improvement in the Twenty-First Century. Kluwer Academic Publishers, Dordrecht, The Netherlands, pp. 53-91.

Gepts, P., Nodari, R., Tsai, S.M., Koinange, E.M.K., Llaca, V., Gilbertson, R., Guzman, P., 1993. Linkage mapping in common bean. Annu. Rep. Bean Improv. Coop. 36, xxiv-xxxviii.

Haley, S.D., Miklas, P.N., Stavely, J.R., Byrum, J., Kelly, J.D., 1993. Identification of RAPD markers linked to a major rust resistance gene block in common bean. Theoret. Appl. Genet. $86,505-512$.

Haley, S.D., Afanador, L.K., Kelly, J.D., 1994a. Selection for monogenic resistance traits with coupling- and repulsion-phase RAPD markers. Crop Sci. 34, 1061-1066.

Haley, S.D., Afanador, L., Kelly, J.D., 1994b. Identification and application of a random amplified polymorphic DNA marker for the $I$ gene (potyvirus resistance) in common bean. Phytopathology 84, 157-160.

Haley, S.D., Afanador, L.K., Miklas, P.N., Stavely, J.R., Kelly, J.D., 1994c. Heterogeneous inbred populations are useful as sources of near-isogenic lines from RAPD marker localization. Theoret. Appl. Genet. 88, 337-342.

He, S., Yu, Z., Vallejos, C., Mackenzie, S., 1995. Pollen fertility restoration by nuclear gene $\mathrm{Fr}$ in CMS common bean: an $\mathrm{Fr}$ linkage map and the mode of $F r$ action. Theoret. Appl. Genet. 90, 1056-1062.

Honma, S., 1956. A bean interspecific hybrid. J. Hered. 47, 217-220.

Ismail, A.M., Hall, A.E., Close, T.J., 1999. Allelic variation of a dehydrin gene cosegregates with chilling tolerance during seedling emergence. Proc. Natl. Acad. Sci. USA 96, 13566-13570.

Johnson, W., Gepts, P., 1999. Segregation for performance in recombinant inbred populations resulting from inter-gene pool crosses of common bean (Phaseolus vulgaris L.). Euphytica 106, 45-56.

Johnson, W., Gepts, P., 2002. The role of epistasis in controlling seed yield and other agronomic traits in an Andean $\times$ Mesoamerican cross of common bean (Phaseolus vulgaris L.). Euphytica 125, 69-79.

Johnson, E., Miklas, P.N., Stavely, J.R., Martinez-Cruzado, J.C., 1995. Coupling and repulsion RAPD markers for markerassisted selection of a rust resistance gene in common bean. Theoret. Appl. Genet. 90, 659-664.

Johnson, W.C., Guzman, P., Mandala, D., Mkandawire, A.B.C., Temple, S., Gilbertson, R.L., Gepts, P., 1997. Molecular tagging of the $b c-3$ gene for introgression into Andean common bean. Crop Sci. 37, 248-254.

Jung, G., Coyne, D.P., Skroch, P.W., Nienhuis, J., Arnaud-Santana, E., Bokos, J., Ariyarathne, H.M., Steadman, J.R., Beaver, J.S., Kaeppler, S.M., 1996a. Molecular markers associated with plant architecture and resistance to common blight, web blight and rust in common bean (Phaseolus vulgaris L.). J. Am. Soc. Hort. Sci. 121, 794-803. 
Jung, G., Coyne, D.P., Skroch, P., Nienhuis, J., Bokosi, J.M., Steadman, J.R., 1996b. RAPD marker linked to a gene for specific rust resistance in common bean. Annu. Rep. Bean Improv. Coop. 39, 59-60.

Jung, G., Skroch, P.W., Coyne, D.P., Nienhuis, J., Arnaud-Santana, E., Ariyarathne, H.M., Kaeppler, S.M., Bassett, M.J., 1997. Molecular-markers-based genetic analysis of tepary beanderived common bacterial blight resistance in different developmental stage of common bean. J. Am. Soc. Hort. Sci. 122, 329-337.

Jung, G., Coyne, D.P., Bokosi, J.M., Steadman, J.R., Nienhuis, J., 1998. Mapping genes for specific and adult plant resistance to rust and abaxial leaf pubescence and their genetic relationship using random amplified polymorphic DNA (RAPD) markers in common bean. J. Am. Soc. Hort. Sci. 123, 859863.

Jung, G., Skroch, P.W., Nienhuis, J., Coyne, D.P., Arnaud-Santana, E., Ariyarathne, H.M., Marita, J.M., 1999. Confirmation of QTL associated with common bacterial blight resistance in four different genetic backgrounds in common bean. Crop Sci. 39, 1448-1455.

Kami, J., Gepts, P., 2000. Development of a BAC library in common bean genotype BAT93. Annu. Rep. Bean Improv. Coop. 43, 208-209.

Kelly, J.D., 1995. Use of random amplified polymorphic DNA markers in breeding for major gene resistance to plant pathogens. HortScience 30, 461-465.

Kelly, J.D., 1997. A review of varietal response to bean common mosaic potyvirus in Phaseolus vulgaris. Plant Varieties and Seeds 10, 1-6.

Kelly, J.D., Miklas, P.N., 1998. The role of RAPD markers in breeding for disease resistance in common bean. Mol. Breed. 4, $1-11$.

Kelly, J.D., Miklas, P.N., 1999. Marker-assisted selection. In: Singh, S.P. (Ed.), Developments in Plant Breeding. Common Bean Improvement in the Twenty-First Century. Kluwer Academic Publishers, Dordrecht, The Netherlands, pp. 93-123.

Kelly, J.D., Young, R.A., 1996. Proposed symbols for anthracnose resistance genes. Annu. Rep. Bean Improv. Coop. 39, 20-24.

Kelly, J.D., Afanador, L., Haley, S.D., 1995. Pyramiding genes for resistance to bean common mosaic virus. Euphytica 82, 207-212.

Kelly, J.D., Stavely, J.R., Miklas, P.N., 1996. Proposed symbols for rust resistance genes. Annu. Rep. Bean Improv. Coop. 39, 25-31.

Khairallah, M.M., Adams, M.W., Sears, B.B., 1990. Mitochondrial DNA polymorphisms of Malawian bean lines: further evidence of two major gene pools. Theoret. Appl. Genet. 80, 753-761.

Koenig, R., Gepts, P., 1989. Segregation and linkage of genes for seed proteins, isozymes, and morphological traits in common bean (Phaseolus vulgaris). J. Hered. 80, 455-459.

Koinange, E.M.K., Singh, S.P., Gepts, P., 1996. Genetic control of the domestication syndrome in common-bean. Crop Sci. 36, 1037-1045.

Kolkman, J.M., Kelly, J.D., 2003. QTL conferring resistance and avoidance to white mold in common bean. Crop Sci. 43, 539-548.
Lamprecht, H., 1961. Weitere Kopplungsstudien an Phaseolus vulgaris mit einer Übersicht über die Koppelungsgruppen. Agric. Hort. Genet. 19, 319-332.

Llaca, V., Gepts, P., 1996. Pulsed field gel electrophoresis analysis of the phaseolin locus region in Phaseolus vulgaris. Genome 39, 722-729.

McClean, P., Lee, R., Otto, C., Gepts, P., Bassett, M., 2002. Molecular and phenotypic mapping of genes controlling seed coat pattern and color in common bean (Phaseolus vulgaris L.). J. Hered. 93, 148-152.

McMillan Jr., R.T., Davis, M.J., McLaughlin, H.J., 1998. PCR evaluation of fourteen bean golden mosaic virus (BGMV) resistant snap bean lines for presence of the virus. Annu. Rep. Bean Improv. Coop. 41, 31-32.

Melotto, M., Kelly, J.D., 1998. SCAR markers linked to major disease resistance genes in common bean. Annu. Rep. Bean Improv. Coop. 41, 64-65.

Melotto, M., Kelly, J.D., 2000. An allelic series at the Co- 1 locus conditioning resistance to anthracnose in common bean of Andean origin. Euphytica 116, 143-149.

Melotto, M., Kelly, J.D., 2001. Fine mapping of the Co-4 locus of common bean reveals a resistance gene candidate, COK-4 that encodes for a protein kinase. Theoret. Appl. Genet. 103, 508-517.

Melotto, M., Afanador, L., Kelly, J.D., 1996. Development of a SCAR marker linked to the $I$ gene in common bean. Genome 39, 1216-1219.

Melotto, M., Balardin, R.S., Kelly, J.D., 2000. Host-pathogen interaction and variability of Colletotrichum lindemuthianum. In: Prusky, D., Freeman, S., Dickman, M.B. (Eds.), Colletotrichum Host Specificity, Pathology, Host-Pathogen Interaction. APS Press, St. Paul, MN, pp. 346-361.

Menancio-Hautea, D., Fatokun, C.A., Kumar, L., Danesh, D., Young, N.D., 1993. Comparative genome analysis of mungbean (Vigna radiata L. Wilczek) and cowpea (V. unguiculata L. Walpers) using RFLP mapping data. Theoret. Appl. Genet. 86, 797-810.

Mendoza, A., Hernandez, F., Hernandez, S., Ruiz, D., Martinez de la Vega, O., de la Mora, G., Acosta, J., Simpson, J., 2000. Identification of $\mathrm{Co}-\mathrm{l}$ anthracnose resistance and linked molecular markers in common bean line A193. Plant Dis. 85, 252-255.

Menéndez, C.M., Hall, A.E., Gepts, P., 1997. A genetic linkage map of cowpea (Vigna unguiculata) developed from a cross between two inbred, domesticated lines. Theoret. Appl. Genet. 95, 1210-1217.

Michelmore, R.W., Paran, I., Kesseli, R.V., 1991. Identification of markers linked to disease resistance genes by bulked segregant analysis: a rapid method to detect markers in specific genomic regions using segregating populations. Proc. Natl. Acad. Sci. USA 88, 9828-9832.

Miklas, P.N., Kelly, J.D., 2002a. The use of MAS to develop pinto bean germplasm possessing $\mathrm{Co}-4^{2}$ gene for anthracnose resistance. Annu. Rep. Bean Improv. Coop. 45, 68-69.

Miklas, P.N., Kelly, J.D., 2002b. Registration of two cranberry bean germplasm lines resistant to bean common mosaic and necrosis potyviruses: USCR-7 and USCR-9. Crop Sci. 42, 673-674. 
Miklas, P.N., Stavely, J.R., Kelly, J.D., 1993. Identification and potential use of a molecular marker for rust resistance in common bean. Theoret. Appl. Genet. 85, 745-749.

Miklas, P.N., Johnson, E., Stone, V., Beaver, J.S., Montoya, C., Zapata, M., 1996. Selective mapping of QTL conditioning disease resistance in common bean. Crop Sci. 36, 1344-1351.

Miklas, P.N., Beaver, J.S., Steadman, J.R., Silbernagel, M.J., Freytag, G.F., 1997. Registration of three bean common mosaic virus-resistant navy bean germplasms. Crop Sci. 37, 1025.

Miklas, P.N., Lambert, S., Mink, G., Silbernagel, M.J., 1998a. Many beans with $b c-3$ resistance to BCMNV are susceptible to BCMV. Annu. Rep. Bean Improv. Coop. 41, 33-34.

Miklas, P.N., Stone, V., Urrea, C.A., Johnson, E., Beaver, J.S., 1998b. Inheritance and QTL analysis of field resistance to ashy stem blight. Crop Sci. 38, 916-921.

Miklas, P.N., Delorme, R., Stone, V., Daly, M.J., Stavely, J.R., Steadman, J.R., Bassett, M.J., Beaver, J.S., 2000a. Bacterial, fungal, virus disease loci mapped in a recombinant inbred common bean population ('Dorado/XAN176'). J. Am. Soc. Hort. Sci. 125, 476-481.

Miklas, P.N., Larsen, R.C., Riley, R., Kelly, J.D., 2000b. Potential marker-assisted selection for $b c-1^{2}$ resistance to bean common mosaic potyvirus in common bean. Euphytica 116, 211-219.

Miklas, P.N., Smith, J.R., Riley, R., Grafton, K.F., Singh, S.P., Jung, G., Coyne, D.P., 2000c. Marker-assisted breeding for pyramided resistance to common bacterial blight in common bean. Annu. Rep. Bean Improv. Coop. 43, 39-40.

Miklas, P.N., Johnson, W.C., Delorme, R., Gepts, P., 2001a. QTL conditioning physiological resistance and avoidance to white mold in dry bean. Crop Sci. 41, 309-315.

Miklas, P.N., Riley, R.H., Grafton, K.F., Gepts, P., $2001 \mathrm{~b}$. Quantitative trait loci (QTL) conditioning resistance to white mold in common bean. In: Proceedings of the Workshop on AXI International Sclerotinia, York, UK, July 8-12, pp. 59-60.

Miklas, P.N., Hang, A.N., Kelly, J.D., Strausbaugh, C.A., Forster, R.L., 2002a. Registration of three kidney bean germplasm lines resistant to bean common mosaic and necrosis potyviruses: USLK-2 light red kidney, USDK-4 dark red kidney, and USWK-6 white kidney. Crop Sci. 42, 674-675.

Miklas, P.N., Pastor-Corrales, M.A., Jung, G., Coyne, D.P., Kelly, J.D., McClean, P.E., Gepts, P., 2002b. Comprehensive linkage map of bean rust resistance genes. Annu. Rep. Bean Improv. Coop. 45, 125-129.

Miklas, P.N., Coyne, D.P., Grafton, K.F., Mutlu, N., Reiser, J., Lindgren, D.T., Singh, S.P., 2003. A major QTL for common bacterial blight resistance derives from the common bean great northern landrace cultivar Montana No. 5. Euphytica (in press).

Mmbaga, M., Steadman, J.R., Stavely, J.R., 1996. The use of host resistance in disease management of rust in common bean. Integr. Pest Manage. Rev. 1, 191-200.

Molina Castenado, A., Beaver, J.S., 1998. Inheritance of normal pod development in bean golden mosaic resistant common beans. Annu. Rep. Bean Improv. Coop. 41, 3-4.

Morales, F.J., Castaño, M., 1992. Increased disease severity induced by some comoviruses in bean genotypes possessing monogenic dominant resistance to bean common mosaic potyvirus. Plant Dis. 76, 570-573.
Mutlu, N., Coyne, D.P., Steadman, J.R., Reiser, J., Sutton, L., 2002. Progress in backcross breeding with RAPD (SCAR) molecular markers to pyramid QTLs for resistance to common bacterial blight in pinto and great northern beans. Annu. Rep. Bean Improv. Coop. 45, 70-71.

Nodari, R.O., 1992. Towards an integrated linkage map of common bean (Phaseolus vulgaris L.). Ph.D. Dissertation. University of California, Davis, CA.

Nodari, R.O., Koinange, E.M.K., Kelly, J.D., Gepts, P., 1992. Towards an integrated linkage map of common bean. I. Development of genomic DNA probes and levels of restriction fragment length polymorphism. Theoret. Appl. Genet. 84, 186-192.

Nodari, R.O., Tsai, S.M., Gilbertson, R.L., Gepts, P., 1993a. Towards an integrated linkage map of common bean. II. Development of an RFLP-based linkage map. Theoret. Appl. Genet. 85, 513-520.

Nodari, R.O., Tsai, S.M., Guzman, P., Gilbertson, R.L., Gepts, P., 1993b. Towards an integrated linkage map of common bean. III. Mapping genetic factors controlling host-bacteria interactions. Genetics 134, 341-350.

Ouédraogo, J.T., Gowda, B.S., Jean, M., Close, T.J., Ehlers, J.D., Hall, A.E., Gillespie, A.G., Roberts, P.A., Ismail, A.M., Bruening, G., Gepts, P., Timko, M.P., Belzile, F.J., 2002. An improved genetic linkage map for cowpea (Vigna unguiculata L.) combining AFLP, RFLP, RAPD and biochemical markers. Génome 45, 175-188.

Park, S.O., Coyne, D.P., Bokosi, J.M., Steadman, J.R., 1999a. Molecular marker linked to genes for specific rust resistance and indeterminate growth habit in common bean. Euphytica 105, 133-141.

Park, S.O., Coyne, D.P., Steadman, J.R., 1999b. Molecular markers linked to the $U r-7$ gene conferring specific resistance to rust in common bean. Annu. Rep. Bean Improv. Coop. 42, $31-32$.

Park, S.O., Coyne, D.P., Mutlu, N., Jung, G., Steadman, J.R., 1999c. Confirmation of molecular markers and flower color associated with QTL for resistance to common bacterial blight in common beans. J. Am. Soc. Hort. Sci. 124, 519-526.

Park, S.O., Coyne, D.P., Jung, G., Skroch, P.W., Arnaud-Santana, E., Steadman, J.R., Ariyarathne, H.M., Nienhuis, J., 2000. Mapping of QTL for seed size and shape traits in common bean. J. Am. Soc. Hort. Sci. 125, 466-475.

Park, S.O., Coyne, D.P., Steadman, J.R., Skroch, P.W., 2001. Mapping of QTL for resistance to white mold disease in common bean. Crop Sci. 41, 1253-1262.

Pastor-Corrales, M.A., Erazo, O.A., Estrada, E.I., Singh, S.P., 1994. Inheritance of anthracnose resistance in common bean accession G 2333. Plant Dis. 78, 959-962.

Pastor-Corrales, M.A., Otoya, M.M., Molina, A., Singh, S.P., 1995. Resistance to Colletotrichum lindemuthianum isolates from Middle America and Andean South America in different common bean races. Plant Dis. 79, 63-67.

Pastor-Corrales, M.A., Stavely, J.R., Kelly, J.D., Grafton, K.F., Steadman, J.R., Coyne, D.P., Lindgren, D.T., Scully, B.T., 2001. Rust and mosaic resistant bean germplasm releases, 19971999. Annu. Rep. Bean Improv. Coop. 44, 101-103. 
Pedraza, F., Gallego, G., Beebe, S., Tohme, J., 1997. Marcadores SCAR y RAPD para la resistencia a la bacteriosis comun (CBB), pp. 130-134. In: Singh, S.P., Voysest, O. (Eds.), Taller de Mejoramiento de Frijol para el Siglo XXI, Bases para una Estrategia para America Latina. CIAT, Cali, Colombia, 559 pp.

Posa-Macalincag, M.C.T., Hosfield, G.L., Grafton, K.F., Uebersax, M.A., Kelly, J.D., 2002. Quantitative trait loci (QTL) analysis of canning quality traits in kidney bean (Phaseolus vulgaris L.). J. Am. Soc. Hort. Sci. 127, 608-615.

Schneider, K.A., Brothers, M.E., Kelly, J.D., 1997. Marker assisted selection to improve drought resistance in common bean. Crop Sci. 37, 51-60.

Schneider, K.A., Grafton, K.F., Kelly, J.D., 2001. QTL analyses of resistance to Fusarium root rot in bean. Crop Sci. 41, 535-542.

Scott, M.E., Michaels, T.E., 1992. Xanthomonas resistance of Phaseolus interspecific cross selections confirmed by field performance. HortScience 27, 250-348.

Silbernagel, M.J., Mills, L.J., Wang, W.Y., 1986. Tanzanian strain of bean common mosaic virus. Plant Dis. 70, 839-841.

Singh, S.P., 1982. A key for identification of different growth habits of Phaseolus vulgaris L. Annu. Rep. Bean Improv. Coop. 25, 92-95.

Singh, S.P., Morales, F.J., Miklas, P.N., Terán, H., 2000. Selection for bean golden mosaic resistance in intra- and inter-racial bean populations. Crop Sci. 40, 1565-1572.

Stavely, J.R., 1984. Genetics of resistance to Uromyces phaseoli in a Phaseolus vulgaris line resistant to most races of the pathogen. Phytopathology 74, 339-344.

Stavely, J.R., 1990. Genetics of rust resistance in Phaseolus vulgaris plant introduction PI181996. Phytopathology 80, 1056 (Abstract).

Stavely, J.R., 1998. Recombination of two major dominant rust resistance genes that are tightly linked in repulsion. Annu. Rep. Bean Improv. Coop. 41, 17-18.

Stavely, J.R., 2000. Pyramiding rust and viral resistance genes using traditional and marker techniques in common bean. Annu. Rep. Bean Improv. Coop. 43, 1-4.

Stavely, J.R., Kelly, J.D., 1996. Evidence for the independence of the $U r-4(U p-2)$ and $U r-6$ rust resistance genes. Annu. Rep. Bean Improv. Coop. 39, 302-302.

Stavely, J.R., McMillan Jr., R.T., 1992. BARC-rust resistant-bush, fresh-market green bean germplasm lines. HortScience 27, 1052-1454.

Stavely, J.R., Steinke, J., 1990. BARC-rust resistant bush wax bean germplasm lines. HortScience 25, 1451-1452.

Stavely, J.R., Steinke, J., McMillan Jr., R.T., Grafton, K.F., Steadman, J.R., Kelly, J.D., Coyne, D.P., Lindgren, D.T., Silbernagel, M.J., 1992. Rust resistant bean germplasm releases. Annu. Rep. Bean Improv. Coop. 35, 228-229.

Stavely, J.R., Kelly, J.D., Grafton, K.F., 1994. BelMiDak-rustresistant navy dry beans germplasm lines. HortScience 29, 709-710.

Stavely, J.R., Kelly, J.D., Grafton, K.F., Mullins, C.A., Straw, A., McMillan Jr., R.T., Beaver, J.S., Miklas, P.N., Steinke, J., Steadman, J.R., Coyne, D.P., Lindgren, D.T., Silbernagel, M.J., 1997. Rust resistant bean germplasm releases, 1994-1996. Annu. Rep. Bean Improv. Coop. 40, 120-121.
Strausbaugh, C.A., Myers, J.R., Forster, R.L., McClean, P.E., 1999. $b c-1$ and $b c-u$ - two loci controlling bean common mosaic virus resistance in common bean are linked. J. Am. Soc. Hort. Sci. 124, 644-648.

Tamulonis, J.P., Lussi, B.M., Hussey, R.S., Parrott, W.A., Boerma, R., 1997. DNA markers associated with resistance to Japanese root-knot nematode in soybean. Crop Sci. 37, 783-788.

Tar'an, B., Michaels, T.E., Pauls, K.P., 2001. Mapping genetic factors affecting the reaction to Xanthomonas axonopodis pv. phaseoli in Phaseolus vulgaris under field conditions. Genome 44, 1046-1056.

Temple, S.R., Morales, F.J., 1986. Linkage of dominant hypersensitive resistance to bean common mosaic virus to seed color in Phaseolus vulgaris. Euphytica 35, 331-333.

Ubi, B.E., Mignouna, H., Thottappilly, G., 2000. Construction of a genetic linkage map and QTL analysis using a recombinant inbred population derived from an intersubspecific cross of cowpea (Vigna unguiculata (L.) Walp.). Breed. Sci. 50, $161-172$.

Urrea, C.A., Miklas, P.N., Beaver, J.S., Riley, R.H., 1996. A codominant RAPD marker useful for indirect selection of BGMV resistance in common bean. J. Am. Soc. Hort. Sci. 121, 1035-1039.

Vallejo, V., Kelly, J.D., 2001. Development of a SCAR marker linked to the Co-5 locus in common bean. Annu. Rep. Bean Improv. Coop. 44, 121-122.

Vallejo, V., Kelly, J.D., 2002. The use of AFLP analysis to tag the $C o-1^{2}$ gene conditioning resistance to bean anthracnose. In: Proceedings of the $\mathrm{X}$ Conference on Plant and Animal Genome, 2002. http://www.intl-pag.org/pag/10/abstracts/ PAGX_P233.html.

Vallejos, E.C., Sakiyama, N.S., Chase, C.D., 1992. A molecular marker-based linkage map of Phaseolus vulgaris L. Genetics 131, 733-740.

Vallejos, C., Skroch, P., Nienhuis, J., 2001. Phaseolus vulgarisThe common bean. Integration of RFLP- and RAPD-based linkage maps. In: Phillips, R., Vasil, I. (Eds.), DNA-based Markers in Plants. Kluwer Academic Publishers, Dordrecht, The Netherlands, pp. 301-317.

Vanhouten, W., Mackenzie, S., 1999. Construction and characterization of a common bean bacterial artificial chromosome library. Plant Mol. Biol. 40, 977-983.

Velez, J.J., Bassett, M.J., Beaver, J.S., Molina, A., 1998. Inheritance of resistance to bean golden mosaic virus in common bean. J. Am. Soc. Hort. Sci. 123, 628-631.

Wallace, D.H., Yourstone, K.S., Masaya, P.N., Zobel, R.W., 1993. Photoperiod gene control over partitioning between reproductive and vegetative growth. Theoret. Appl. Genet. 86, 6-16.

Weeden, N.F., 1984. Linkage between the gene coding the small subunit of ribulose biphosphate carboxylase and the gene coding malic enzyme in Phaseolus vulgaris. Annu. Rep. Bean Improv. Coop. 27, 123-124.

Weeden, N.F., Liang, C.Y., 1985. Detection of a linkage between white flower color and Est-2 in common bean. Annu. Rep. Bean Improv. Coop. 28, 87-88. 
Weeden, N.F., Timmerman, G.M., Hemmat, M., Kneen, B.E., Lodhi, M.A., 1992. Inheritance and reliability of RAPD markers. In: Proceedings of the CSSA-ASHS-AGA Joint Plant Breeding Symposium Series, Minneapolis. Crop Science Society of America, Madison, WI, pp. 12-17.

Welsh, W., Bushuk, W., Roca, W., Singh, S.P., 1995. Characterization of agronomic traits and markers of recombinant inbred lines from intra- and inter-racial populations of Phaseolus vulgaris L. Theoret. Appl. Genet. 91, 169-177.

Witsenboer, H., Kesseli, R.V., Fortin, M.G., Stanghellini, M., Michelmore, R.W., 1995. Sources and genetic structure of a cluster of genes for resistance to three pathogens in lettuce. Theoret. Appl. Genet. 91, 178-188.

Young, R.A., Kelly, J.D., 1996a. RAPD markers flanking the Are gene for anthracnose resistance in common bean. J. Am. Soc. Hort. Sci. 121, 37-41.

Young, R.A., Kelly, J.D., 1996b. Characterization of the genetic resistance to Colletotrichum lindemuthianum in common bean differential cultivars. Plant Dis. 80, 650-654.
Young, R.A., Kelly, J.D., 1997. RAPD markers linked to three major anthracnose resistance genes in common bean. Crop Sci. 37, 940-946.

Young, R.A., Melotto, M., Nodari, R.O., Kelly, J.D., 1998. Marker assisted dissection of the oligogenic anthracnose resistance in common bean cultivar G 2333. Theoret. Appl. Genet. 96, 87-94.

Yu, Z.H., Stall, R.E., Vallejos, C.E., 1998. Detection of genes for resistance to common bacterial blight of beans. Crop Sci. 38, 1290-1296.

Yu, K.F., Park, S.J., Poysa, V., 1999. Abundance and variation of microsatellite DNA sequences in beans (Phaseolus and Vigna). Genome 42, 27-34.

Yu, K., Park, S.J., Poysa, V., 2000a. Marker-assisted selection of common beans for resistance to common bacterial blight: efficacy and economics. Plant Breed. 119, 411-415.

Yu, K., Park, S., Poysa, V., Gepts, P., 2000b. Integration of simple sequence repeat (SSR) markers into a molecular linkage map of common bean (Phaseolus vulgaris L.). J. Hered. 91, 429-434. 